\title{
GEOMATIC TECHNIQUES APPLIED FOR REMOTE DETERMINATION OF THE HAY QUANTITY IN AGROSILVOPASTORAL SYSTEMS
}

\author{
Loredana Copăcean $^{1}$, Luminiţa Cojocariu ${ }^{1,2 *}$, M. Simon ${ }^{1}$, I. Zisu ${ }^{3}$, C. Popescu ${ }^{1}$ \\ ${ }^{1}$ Banat's University of Agricultural Sciences and Veterinary Medicine „King Mihai I of \\ Romania" from Timişoara, \\ ${ }^{2}$ Agricultural Research and Development Station Lovrin, Romania \\ ${ }^{3}$ West University of Timişoara, Romania \\ * Corresponding author: luminitacojocariu @yahoo.com
}

Keywords: geomatic, agrosilvopastoral system, quantity, volume, hay.

\begin{abstract}
The paper presents a descriptive model, applicable in agricultural theory and practice, for determining the quantity of alfalfa hay obtained from a land surface, using remote investigations, by geospatial methods and means. The working algorithm was tested in a rural area located in the northern part of Romania, in the Humor Depression, and the data acquisition was made with DJI Phantom 4 Pro Unmanned Aerial Vehicle equipment. For the automated calculation of the amount of alfalfa hay harvested from a certain surface and stored as haystacks, the following steps were carried out: processing the images acquired with the drone to obtain the point clouds, determining the 3D model of the haystacks, calculating the volume of hay stored in the stacks and converting the volume in quantity of hay/surface. As a result of the measurements and calculations carried out, a quantity of hay of 11.96 tons/ha was obtained, data verified and validated by the researches from the specialized literature. Compared with the agronomic methods, the use of the geomatics techniques, to determine the quantity of hay harvested from an agricultural area, presents a series of practical and economic advantages: they exclude the manual measurements in the field and, therefore, the displacements on extended surfaces; reduce the working time; have high precision because, for the estimation of the haystacks volume, three-dimensional models are used, instead of the traditional mathematical formulas. At the same time, geospatial data is acquired through drone flying, which can be used in other types of analysis. The working algorithm can also be applied to other studied objectives or research topics.
\end{abstract}

\section{INTRODUCTION}

The agrosilvopastoral system represents a form of „spatial and temporal arrangement" (FAO and ICRAF, 2019, pag. 1) in which several elements are interwoven: arable crops, pastures/hay, shrub species, trees, fruit trees and/or 
animals (Cojocariu et al., 2014, Chará et al., 2019). These long-term production systems are considered the main form of agricultural land use in many rural areas around the globe (Bell and Moore, 2012).

The agrosilvopastoral systems promote sustainable agriculture, by reducing the impact on natural resources, targeting animal welfare and, implicitly, improving food security and providing a number of ecosystem services and environmental benefits (Jose, 2009). These systems include cost and risk reductions, they ensure increased land efficiency and they enhance biological diversity: living environment for birds (Broom et al., 2013; Rain et al., 2019), habitats and passing corridors for wild animals, also participating in the decreasing of greenhouse gases (Peri et at., 2017).

In the traditional systems of animal breeding from the rural area of Romania, by combining the vegetal carpet of grasslands, shrubs and trees and that of crops (alfalfa, clover, maize) from the same area, a larger amount of high quality feed is created, reflected in better performance in animal production (Hoancea et al., 2017).

Broadly speaking, the use of drones in different segments of the agricultural field is one of the most important innovations (Raparelli and Bajocco, 2019), with significant results, from the analysis of soil preparation works (Tripicchio et al., 2015), precision agriculture (Stafford, 2002; Zhang and Kovacs, 2012; Rokhmana, 2015; Mahajan and Bundel, 2017; Puri et al., 2017; Shamshiri et al., 2018), mapping and monitoring of vegetation (Cohen et al., 2018; Sona et al., 2016), to evaluation and prediction (Themistocleus, 2017; Sanches et al., 2018; Herrmann et al., 2020).

Due to their particularities, agrosilvopastoral systems are the central object of the research in different domains or they are constituted as the subject of multidisciplinary researches, in which the pratological methods are supplemented with geomatical methods and techniques, more „flexible" and, in some cases, remote applied. In this way, some manual workflow operations are replaced or even eliminated.

Regarding the exploitation in agrosilvopastoral systems, based on pragmatic considerations, this study proposes a descriptive model, applicable in agricultural theory and practice, for determining the quantity of alfalfa hay obtained from a surface unit, through remote investigations, by geospatial methods and means, with Unmanned Aerial Vehicle (UAV) equipment.

The remote determination of hay quantity is of importance in making decisions regarding the feed reserve, as well as the adequate provision of the necessary means of transport and labor and, finally, the optimization of costs, the studied areas being sometimes at great distances from farms. 


\section{MATERIALS AND METHODS}

The study area is located in the northern part of Romania (fig. 1), in the Humor Depression, at altitudes between 490 - $557 \mathrm{~m}$.

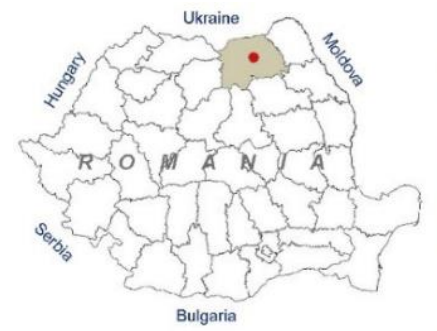

Coordinates: $47^{\circ} 36^{\prime} 53^{\prime \prime} \mathrm{N}$ $25^{\circ} 50^{\prime} 43^{\prime \prime} \mathrm{E}$

Administrative-territorial unit

Mănăstirea Humorului

Suceava County, Romania

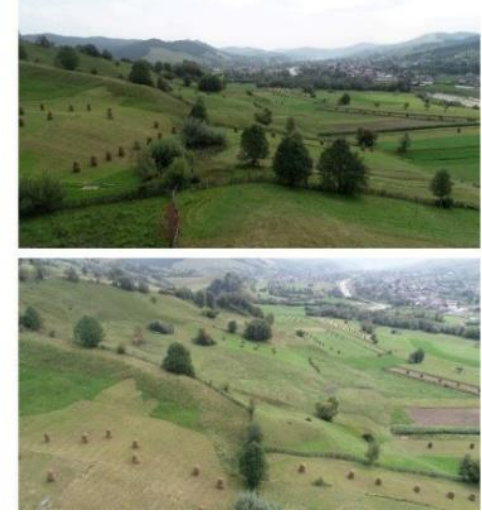

Figure 1. Geographical location of the study area

The working methodology applied in the research involves going through several stages, synthetically presented in figure 2 .

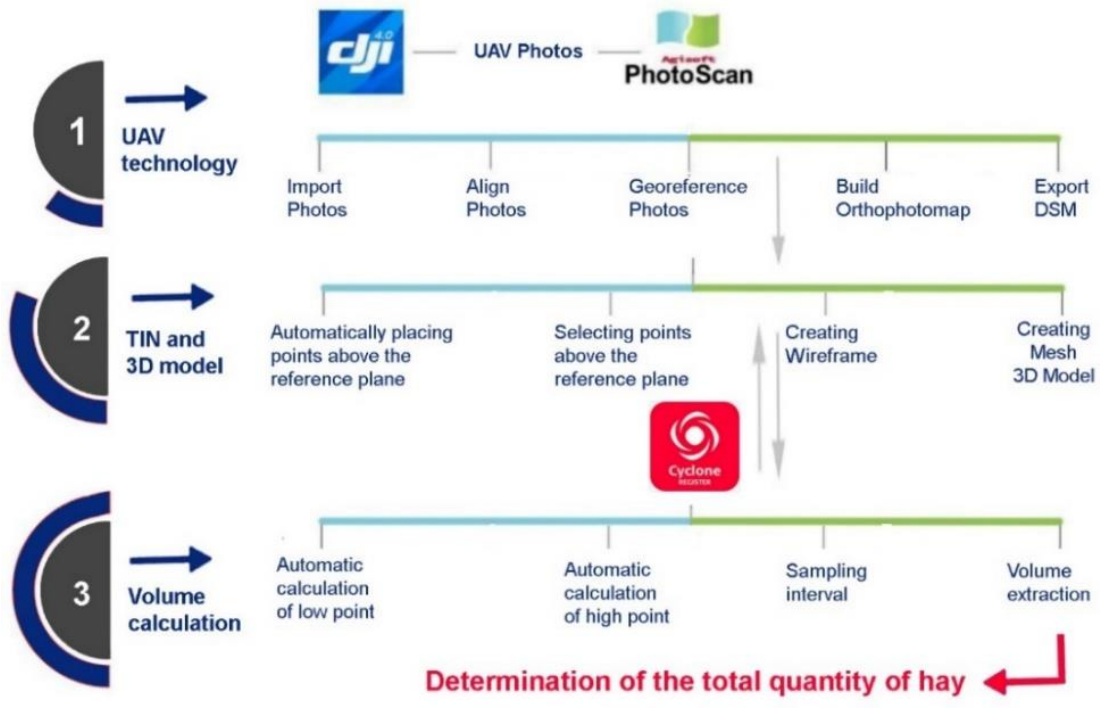

Figure 2. Research methodology stages 
Using UAV equipment (DJI Phantom 4 Pro) an area of 8.44 ha was flown over. This surface belongs to a traditional agrosilvopastoral system consisting of: grasslands with shrubs and fruit trees, hedgerows, fodder crops on arable land with different ways of use (alfalfa, red clover and maize) and the related animals (cows, horses, sheep, pigs). The interest area of this study consists into a surface of 0.50 ha of mowed alfalfa; the hay being manually deposited on the ground, in traditional stacks. In this situation, the haystacks have different shapes and sizes.

The volume of alfalfa hay manually placed in each stack was determined by geomatic methods (3D image measurements), after which the weight of the alfalfa hay being calculated using the formula proposed by Horablaga and Cojocariu (2006):

(relation 1)

where: $\mathrm{G}=$ the weight of feed $(\mathrm{kg}) ; \mathrm{V}=$ the volume of feed determined; $\mathrm{g}=$ the weight of one $\mathrm{m}^{3}$ of stored feed.

According to the data from the specialized literature (Horablaga and Cojocariu, 2006), one $\mathrm{m}^{3}$ of alfalfa hay weighs $100 \mathrm{~kg}$, after storage.

Considering that this study presents a working model, and each stage of the research methodology has concrete results, its detailing will be done in the section „Results and discussions”.

\section{RESULTS AND DISCUSSIONS}

The researches presented in this paper aimed a traditional agrosilvopastoral system, composed of agricultural surfaces with different ways of use (grasslands and forage crops in arable land). The animals occupy by rotation, in certain time intervals, different sequences in this system.

The algorithm applied in this study is presented below.

\subsection{Data acquisition with UAV equipment}

For the study area, the data acquisition was made with DJI Phantom 4 Pro type equipment, with FC6310, $8.8 \mathrm{~mm}$ camera. The research of the area involved the planning of the flight mission, the actual photography and the processing of the images with the specialized software Pix4Dcapture and Agisoft PhotoScan Professional (fig. 3), according to the methodology described in their technical manuals. 


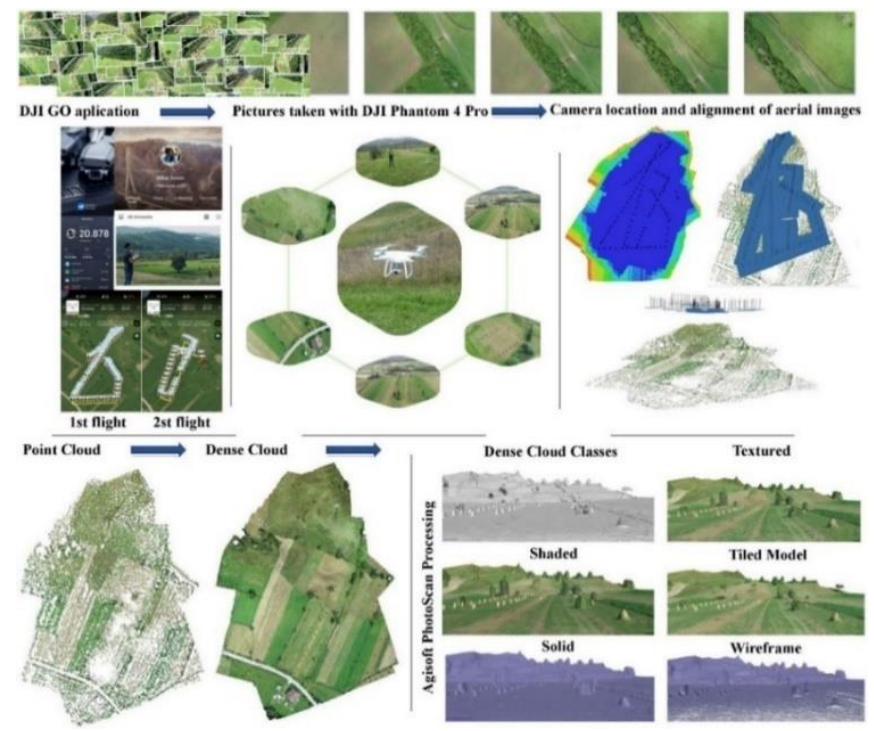

Figure 3. Data acquisition with UAV equipment

Following the processing of the data acquired with the drone results at least three products that can be used, both to achieve the objectives proposed in this study, as well as in other territorial or pratological analyzes:

- $\quad$ the point clouds (fig. 3), used for 3D representations and subsequently for volume calculation;

- $\quad$ the Digital Land Model (DLM), the Digital Surface Model (DSM) and the Digital Elevation Model (DEM), generated from point clouds, useful for analyzing the relief or other physical-geographical aspects (fig. 4);

- detailed images (photos) of the researched area (fig. 3), useful in the analysis of vegetation, the land use etc.

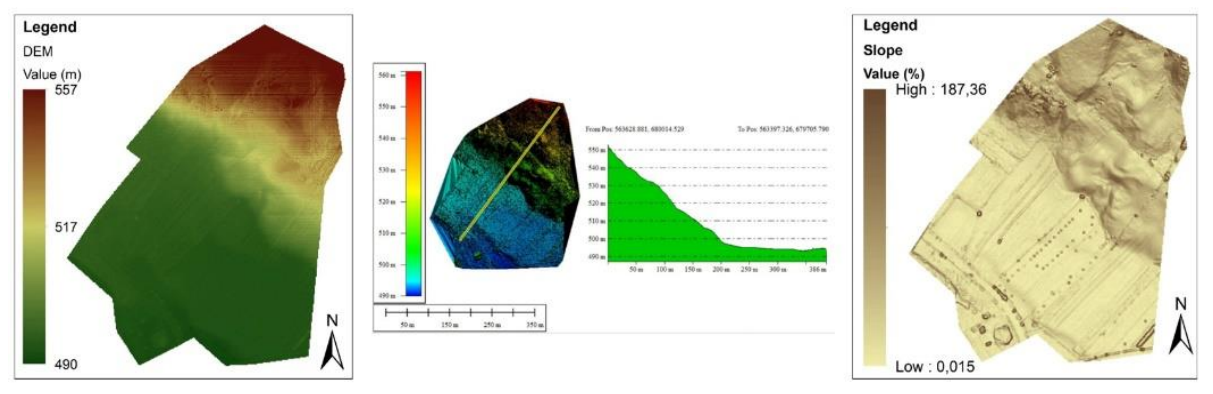

Figure 4. Characteristics of the researched area 
The use of drones in studing the different components of the pastoral space, considering its size and complexity, is an increasingly used method, with remarkable results, both internationally and in Romania (Capolupo et al., 2015; Forsmoo et al., 2018; Sun et al., 2018; Simon et al., 2018). In another context, the structure of the analyzed agrosilvopastoral system is divided, in vertical stratification, into different altimetric floors, between $557 \mathrm{~m}$, in the highest area, and $490 \mathrm{~m}$, in the low areas (fig. 4). In these spatial arrangements, the species of trees are related to the vegetation from the grasslands where they inhabit, and the hedgerows delimit the small surfaces of forage crops, semi-mechanized maintained.

A series of works highlight that these integrated production systems engage temporal and spatial interactions at different levels (Roese et al., 2018), which involve the exploitation of animals and field crops within the same area, simultaneously or disjointed, with a succession within them (Moraes et al., 2014).

\subsection{Delimitation of the interest area}

From the point of view of land use, the analyzed agrosilvopastoral system is composed of pasture plots, exploited by grazing/mowing, hayfields plots, exploited by mowing and forage crops in arable land, from which the feed needs for domestic animals are supplemented, especially in winter (fig. 5). The fact that these plots of land belong to different owners translates to different exploitation technologies.

The mechanized harvesting and storage of the hay production allows to appreciate the quantity obtained on the surface unit by the standard dimensions of the hay bales, but in the case of exploitation in the traditional system, the production is stored manually as haystacks of different sizes. Based on this consideration, the testing of the geomatic model for calculating the quantity of hay was made on a plot cultivated with alfalfa exploited in this way.

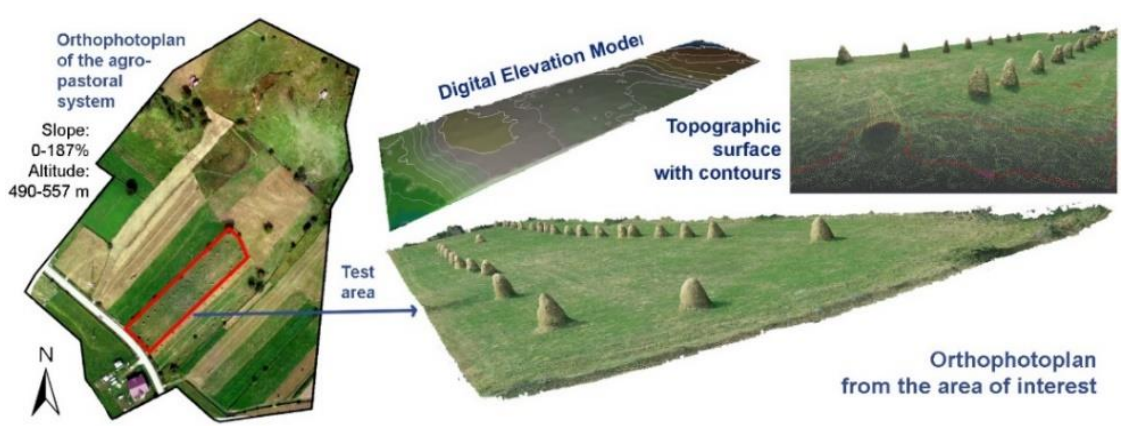

Figure 5. The study area 
From the considered agrosilvopastoral system, by the help of specialized software Leica Cyclone Model, from the point clouds and the orthophotoplan obtained by drone overflowing, the plot of alfalfa with the surface of 0.50 ha was delimited and extracted (fig. 5). The hay production on this surface has been storage into 31 haystacks of different sizes (in the case of large areas, automated applications can be used for their counting). Of all these haystacks, for the calculation of the average volume of stored hay, respectively of the quantity/ha, seven ticks were selected, randomly distributed on the field, according to figure 6 .

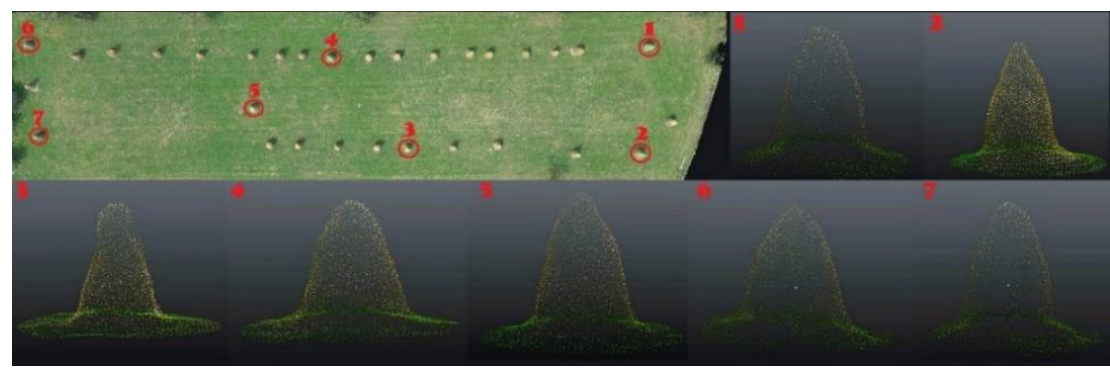

Figure 6. Random selection of test-objectives

\subsection{Generation of TIN structure and 3D model}

The specialized literature shows that, in the multidisciplinary research involving the agricultural environment, the clouds of points obtained through different technologies are being used more and more (Honkavaara et al., 2012; Koenig et al., 2015). In the case of this study, the point clouds, obtained with UAV equipment, are processed for calculating the volume of hay that was harvested, at one mowing, from the selected surface.

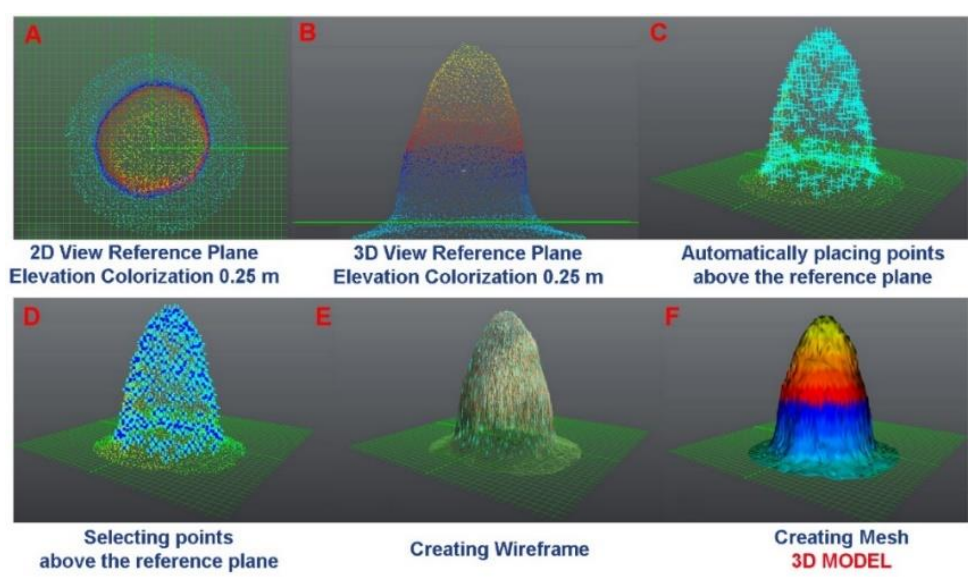

Figure 7. Generation of 3D model of test haystacks 
In order to calculate the hay volume, it was previously necessary to generate the 3D model of the selected haystacks (fig. 7).

On the point clouds, in the software Leica Cyclone the following algorithm was applied for each stack of alfalfa hay (fig. 7): establishing the reference plan, depending on the topographic surface; choosing and selecting the points according to the reference plan; creation of the TIN (Triangular Irregular Network) structure; 3D model generation.

With the presented algorithm, the 3D model of the entire topographic surface can be realized, useful in morphometric, pedological or spatial planning researches.

\subsection{Volume of hay determination}

Based on the 3D model of the alfalfa haystacks, obtained in the previous step, it was possible to calculate the volume of hay stored in each of the seven teststacks (fig. 8).

The following working algorithm was applied: selecting the minimum point and the maximum point, from the base and from the top of the haystacks; generating the „content” (sampling interval - its density can be determined according to necessity), respectively the network of lines that fill the studied object, based on which the volume was determined.

Considering the manual execution of the haystacks, their volume varies between $1.05-2.65 \mathrm{~m}^{3}$ (fig. 8).

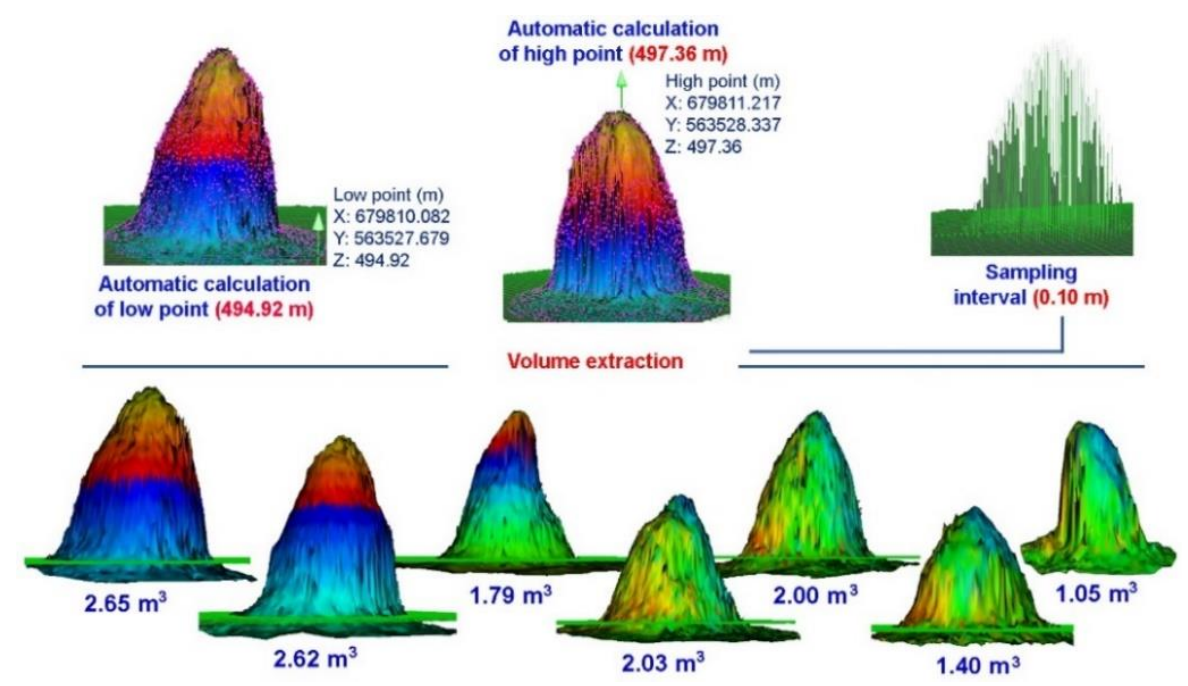

Figure 8. Calculation of the volume of haystacks 


\subsection{Determination of the quantity of hay/surface unit}

In order to determine the quantity of alfalfa hay, the previously determined volume (average value) and the weight of the hay were taken into account, according to the specialized literature (Horablaga and Cojocariu, 2006).

According to figure 9, the volume of haystacks varies between $1.05-2.65 \mathrm{~m}^{3}$, and the average volume is $1.93 \mathrm{~m}^{3}$.

Knowing that $1 \mathrm{~m}^{3}$ of alfalfa hay, after storage, is equivalent to $100 \mathrm{~kg}$, it turns out that a stack of alfalfa hay has an average weight of $193 \mathrm{~kg}$.

On the surface of 0.50 ha were identified 31 stacks of alfalfa hay, so it results that the amount of hay obtained is $5,983 \mathrm{~kg}$.

\begin{tabular}{|c|c|c|}
\hline $\begin{array}{c}\text { Haystack } \\
\text { s }\end{array}$ & $\begin{array}{c}\text { Volume } \\
\left(\mathbf{m}^{3}\right)\end{array}$ & \multirow{4}{*}{$\begin{array}{c}\text { Average volume } / \text { haystack: } \\
1.93 \mathrm{~m}^{3} \Leftrightarrow 193 \mathrm{~kg} \\
\left(1 \mathrm{~m}^{3}=100 \mathrm{~kg} \text { after }\right. \\
\text { placement })\end{array}$} \\
\hline 1 & 2.65 & \\
\hline 2 & 2.62 & \\
\hline 3 & 1.79 & \\
\hline 4 & 2.03 & \multirow{4}{*}{$\begin{array}{l}\text { Amount of hay/surface: } \\
5.983 \mathrm{~kg} \Leftrightarrow 5.98 \text { tone }\end{array}$} \\
\hline 5 & 2.00 & \\
\hline 6 & 1.40 & \\
\hline 7 & 1.05 & \\
\hline \multicolumn{2}{|c|}{$\begin{array}{l}\text { The surface of the } \\
\text { area of interest: } 0.50\end{array}$} & $\begin{array}{l}\text { Volume of hay/ha: } \\
11.96 \text { tone }\end{array}$ \\
\hline
\end{tabular}

Figure 9. Determination of the quantity of hay/surface unit

The results of the research were reported on an area of 0.50 ha, but, depending on the need or the desired analysis, the workflow can be applied on different land surfaces, regardless of their size.

\section{CONCLUSIONS}

In our country, the agrosilvopastoral systems are based on traditional local practices, with reduced mechanization possibilities. With all these shortcomings, they support the economy of Romania's disadvantaged hill and mountain areas. Transdisciplinary research has a special role, by creating analysis models that can be used by farmers, in order to make working conditions more efficient and to increase the yield of agricultural holdings.

The possibility of using drones in the research of agrosilvopastoral systems and, in more detail, for determining the quantity of hay harvested from a given surface, constitutes a major advantage for the agricultural practice. Using this method the following are possible: reducing working time, avoiding displacement 
on the field (sometimes on very large surfaces), eliminating restrictions imposed by weather or relief conditions, but also collecting additional data and information that can be used in complexes analyzes for the target area.

The application of geomatics techniques in agronomic researches, materialized by a geospatial algorithm that involves the remote study of agricultural surfaces, in this case of fodder crops, can be extrapolated to other components or structural elements in the domain. The major advantage consists into a complex remote study, without coming into direct contact with the study environment.

\section{References}

Bell, L.W., Moore, A.D., (2012). Integrated crop-livestock systems in Australian agriculture: Trends, drivers and implications. Agricultural Systems, 111 (1): 1-12. doi.org/10.1016/j.agsy.2012.04.003

Broom, D.M., Galindo, F.M., Murgueitio, E., (2013), Sustainable, efficient livestock production with high biodiversity and good welfare for animals. Proceedings of the Royal Society B: Biological Sciences, 280 (1771): 2013-2025, doi: https://doi.org/10.1098/rspb.2013.2025

Capolupo, Alessandra, Kooistra, L., Berendonk, Clara, Boccia, L., Suomalainen, J., (2015), Estimating Plant Traits of Grasslands from UAV-Acquired Hyperspectral Images, A Comparison of Statistical Approaches. ISPRS International Journal of GeoInformation, 4 (4): 2792-2820. doi.org/10.3390/ijgi4042792

Carvalho, P.C.F., Moraes, A., Pontes, L.S., Anghinoni, I., Sulk, R.M., Batello, C., (2014), Definitions and terminologies for Integrated Crop-Livestock System, Revista Ciencia Agronomica, 45 (5): 1040-1046, https://doi.org/10.1590/S180666902014000500020

Chará, J., Reyes, E., Peri, P., Otte, J., Arce, E., Schneider, F., (2019), Silvopastoral Systems and their Contribution to Improved Resource Use and Sustainable Developmen Goals: Evidence from Latin America. FAO, CIPAV and Agri Benchmark, Cali, 60 pp.

Cojocariu, Luminița, Săndoiu, I.C., Horablaga, N.M., Borozan, Aurica Breica, Micu, Lavinia Madalina, Bordean, Despina-Maria, (2014), Systems for increasing the efficiency of submountain and mountain areas in Banat Mountains, Agrobuletin AGIR, Anul VI, 1-2 (18): 12-19

Cohen, O., Cartier, A., Ruz, Marie-Hélène., (2018), Mapping Coastal Dunes Morphology and Habitats Evolution Using UAV and Ultra-High Spatial Resolution Photogrammetry, International Workshop „Management of coastal dunes and sandy beaches", Dunkirk, 12-14 june 2018

Forsmoo, J., Anderson, K., Macleod, C.J.A., Wilkinson, M.E., Brazier, R., (2018), Drone-based structure-from-motion photogrammetry captures grassland sward height 
variability, Journal of Applied Ecolology, $55 \quad$ (6): 2587-2599. https://doi.org/10.1111/1365-2664.13148

Herrmann, I., Bdolach, E., Montekyo, Y., Rachmilevitch, S., Townsend, P.A., Karnieli, A., (2020), Assessment of maize yield and phenology by drone-mounted superspectral camera, Precision Agriculture, 21, 51-76. https://doi.org/10.1007/s11119-019-09659-5

Hoancea, Lia, Copacean, Loredana, Bordean, Despina Maria, Cojocariu, Luminița, (2017), Analysis of pasture vegetation in the west of Romania in correlation with pastoral traditions, International Multidisciplinary Scientific GeoConference: SGEM; Sofia, Conference Proceedings, 17 (52): 33-40, https://doi.org/10.5593/sgem2017/52

Honkavaara, E., Kaivosoja, J., Mäkynen, J., Pellikka, I., Pesonen, L., Saari, H., Salo, H., Hakala, T., Marklelin, L., Rosnell, T., (2012), Hyperspectral reflectance signatures and point clouds for precision agriculture by light weight UAV imaging system. In XXII ISPRS Congress 2012: Technical Commission VII, Melbourne, Australia, ISPRS Annals of the Photogrammetry, Remote Sensing and Spatial Information Sciences, Volume I-7: 353-358. https://doi.org/10.5194/isprsannals-I-7353-2012

Horablaga, M.N., Cojocariu, Luminiţa, (2006), Managementul pajiştilor şi al culturilor furajere, Editura Eurostampa, Timişoara.

Jose, S., (2009), Agroforestry for ecosystem services and environmental benefits: an overview, Agroforest Systems, 76: 1-10. https://doi.org/10.1007/s10457-009-9229-7

Koenig, Kristina, Höfle, B., Hämmerle, M., Jarmer, T., Siegmann, B., Lilienthal, H., (2015), Comparative classification analysis of post-harvest growth detection from terrestrial LiDAR point clouds in precision agriculture, ISPRS Journal of $\begin{array}{llll}\text { Photogrammetry and Remote } & \text { 112-125. }\end{array}$ doi.org/10.1016/j.isprsjprs.2015.03.003

Mahajan, U., Bundel, B.R., (2017), Drones for Normalized Difference Vegetation Index (NDVI), to Estimate Crop Health for Precision Agriculture: A Cheaper Alternative for Spatial Satellite Sensors, In Proceedings of the International Conference on Innovative Research in Agriculture, Food Science, Forestry, Horticulture, Aquaculture, Animal Sciences, Biodiversity, Ecological Sciences and Climate Change (AFHABEC-2016). Jawaharlal Nehru University, New Delhi, India: 28-41 [link]

de Moraes, A., de F. Carvalho, P.C., Anghinoni, I., Lustosa, S.B.C., de A. Costa, S.E.V.G., Kunrath, T.R., (2014), Integrated crop-livestock systems in the Brazilian subtropics, European Journal of Agronomy, 57: 4-9. https://doi.org/10.1016/j.eja.2013.10.004

Peri, P.L., Banegas, Natalia, Gasparri. I., Carranza, C.H., Rossner, B., Pastur, G.M., Cavallero, Laura, López, D.R., Loto, D., Fernández, P., Powel, Priscila, Ledesma, Marcela, Pedraza, R., Albanesi, Ada, Bahamonde, H., Eclesia, Roxana Paola, Piñeiro, G., (2017), Carbon Sequestration in Temperate Silvopastoral Systems, Argentina, In Montagnini, F. (Ed.) Integrating Landscapes: Agroforestry for Biodiversity Conservation and Food Sovereignty, Chapter 19, pp 453-478. Advances in Agroforestry 12, Springer International Publishing. https://doi.org/10.1007/978-3319-69371-2_19 
100 Geomatic techniques applied for remote determination of the hay quantity in agrosilvopastoral systems

Puri, V., Nayyar, A., Raja, L., (2017), Agriculture drones: A modern breakthrough in precision agriculture, Journal of Statistics and Management Systems, 20 (4): 507-518. doi.org/10.1080/09720510.2017.1395171

Rain, P., Bostan, C., Copăcean, Loredana, Hoancea, Lia, Cojocariu, Luminița, (2019), Management of grasslands for the conservation of the bird species Lanius Minor and Falco Vespertinus in accordance with the Common Agricultural Policy, in Romania. Case study, Research Journal of Agricultural Science, 51 (2): 45-5, [link]

Raparelli, Elisabetta, Bajocco, Sofia, (2019), A bibliometric analysis on the use of unmanned aerial vehicles in agricultural and forestry studies, International Journal of Remote Sensing, 40 (24): 9070-9083. doi.org/10.1080/01431161.2019.1569793

Roese, A.D., Junior, P.J.R., Porfírio-da-Silva, V., May De Mio, Louise Larissa, (2018), Agrosilvopastoral system enhances suppressiveness to soybean damping-off caused by Rhizoctonia solani and alters Fusarium and Trichoderma population density, Acta Scientiarum. Agronomy, 40, e35075. doi.org/10.4025/actasciagron.v40i1.35075

Rokhmana, C.A. (2015), The Potential of UAV-based Remote Sensing for Supporting Precision Agriculture in Indonesia, Procedia Environmental Sciences 24: 245-253. https://doi:10.1016/j.proenv.2015.03.032

Sanches, G.M., Duft, D.G., Kölln, O.T., Dos Santos Luciano, A.C., Quassi De Castro, S.G., Okuno, F.M., Junqueira Franco, H.C., (2018), The Potential for RGB Images Obtained Using Unmanned Aerial Vehicle to Assess and Predict Yield in Sugarcane Fields, International Journal of Remote Sensing 39 (15-16): 5402-5414. https://doi:10.1080/01431161.2018.1448484

Shamshiri, R.R., Weltzien, Cornelia, Hameed, I.A., Yule, I.J., Grift, T.E., Balasundram, S.K., Pitonakova, Lenka, Ahmad, D., Chowdhary, G., (2018), Research and Development in Agricultural Robotics: A Perspective of Digital Farming, International Journal of Agricultural and Biological Engineering 11 (4): 114, doi: https://doi.org/10.25165/j.ijabe.20181104.4278

Simon, M., Copăcean, Loredana, Cojocariu, Luminița, (2018), U.A.V. Technology for the detection of spatio-temporal changes of the useful area for forage of grassland, Research Journal of Agricultural Science, 50 (4): 332-341, [link]

Sona, Giovanna, Passonia, D., Pinto, L., Pagliari, Diana, Masseroni, D., Ortuani, Bianca, Facchi, Arianna, (2016), UAV Multispectral Survey to Map Soil and Crop for Precision Farming Applications, The International Archives of the Photogrammetry, Remote Sensing and Spatial Information Sciences, 41: 1023-1029. https://doi.org/10.5194/isprs-archives-XLI-B1-1023-2016

Stafford, J.V., (2002), Implementing Precision Agriculture in the 21st Century, Journal of Agricultural Engineering Research 76 (3): 267-275. doi:10.1006/jaer.2000.057

Sun, Y., Yi, S., Hou, F., (2018), Unmanned aerial vehicle methods makes species composition monitoring easier ingrasslands, Ecological Indicators, 95 (1): 825-830. doi.org/10.1016/j.ecolind.2018.08.042

Themistocleus, K., (2017), The use of UAVs for monitoring land degradation, Earth Resources and Environmental Remote Sensing/GIS Applications VIII, edited by Michel., U., Schultz K., Proceedings of SPIE Remote Sensing, Volume 10428,104280E-1; doi: 10.1117/12.2279512 
Tripicchio, P., Satler, M., Dabisias, G., Ruffaldi, E., Avizzano, C.A., (2015), Towards smart farming and sustainable agriculture with drones, In Proceedings of the 2015 International Conference on Intelligent Environments, Prague, 15-17 July 2015: 140143. DOI: $10.1109 /$ IE.2015.29

Zhang, C., Kovacs, J.M., (2012), The application of small unmanned aerial systems for precision agriculture: a review, Precision Agriculture 13: 693-712. doi: https://doi.org/10.1007/s11119-012-9274-5

•.• FAO and ICRAF. (2019). Agroforestry and tenure. Forestry Working Paper no. 8. Rome. 40 pp. Licence: CC BY-NCSA 3.0 IGO

•• Agisoft PhotoScan User Manual Professional Edition, Version 1.4, https://www.agisoft.com/pdf/photoscan-pro_1_4_en.pdf accessed in 15.02.2020

•.• Leica Cyclone Model Documentation - https://leica-geosystems.com/products/laserscanners/software/leica-cyclone/leica-cyclone-model accessed in 14.02.2020

•• User Manuale Pix4Dcapture https://support.pix4d.com/hc/en-us/sections/200733429Getting-Started-User-Manuals-Special-Install accessed in 15.02.2020

(C) 2020 by the authors. Licensee UAIC, Iasi, Romania. This article is an open access article distributed under the terms and conditions of the Creative Commons Attribution (CC BY-NC-ND) license (https://creativecommons.org/licenses/by-nc-nd/4.0). 